\title{
BANKACILIK SEKTÖRÜNDE ÖRGÜTSEL İLETISŞIM KAYNAKLI SORUNLARIN İNCELENMESİ: ELAZIĞ VE MALATYA ILLERINNDE YAPILAN BİR ARAŞTIRMA
}

\author{
Examination Of Problems Related To Organizational Communication In The Banking \\ Sector: A Study Executed In The Cities Of Elazı ̆̆ And Malatya
}

Özcan DEMIR ${ }^{1}$

Eray Ekin SEZGiN ${ }^{2}$

\begin{abstract}
ÖZET
Kurumsal kültürün yerleştirilmesi, kurumun örgütsel strateji ve amaçlarının gerçekleşme koşulu hiç şüphesiz kurumun iyi işleyen bir örgütsel iletişim kanalına sahip olmasından geçmektedir. Kurumun verimli ve karlı çalışmasında da bu unsur önemli bir yere sahip olmaktadır. Bankacılık sektörü, iş yoğunluğu, stresi, personelin statüsü ve kariyer gelişim süreçleri açısından hizmet sektöründe önemli bir konuma sahip bulunmaktadır.

Çalışmamızda, bankacılık sektöründe yöneticiler ile işgörenler arasındaki örgütsel iletişimin boyutları incelenmeye çalışılmıştır. İşgörenler; kararlara katılmayı, işle ilgili fikirlerinin alınmasını önemli görmüş olup, takım çalışma ruhunun oluşumunda iletişim faktörlerinin önemi ortaya konulmuş̧ur. Sağliklı bir çalışma ortamının tesisi, hoşgörü ve adalete uygun yaklaşımlar işgörenlerin örgütsel iletişimine yön veren unsurlar olarak tespit edilmiştir. Çıkan sonuçlar, katılımcıların yönetici ve diğer banka çalışanları arasındaki iletişim sorunlarının değerlendirmesinde cinsiyet, bankadaki çalışma süresi, eğitim düzeyi ve iletişim ile ilgili eğitim alma durumlarının çok fazla farklılık göstermemesine rağmen, yaş, statü, meslek durumlarında farklılıklar ortaya çıktığı görülmektedir.
\end{abstract}

Anahtar Kelimeler: Bankacılık Sektörü, Örgütsel İletişim, İletişim Sorunlarına Algı Düzeyi

\section{ABSTRACT}

There is no doubt that having of the corporate a well-functioning organizational communication channel is a must to fix up the corporate culture and realize the organizational strategy and goals of the institution. This element is also has an important place for the efficient and profitable running of the institution. Banking sector has an important place within the service industry due to its workload, stress, the status of the staff and career development process.

In the study, the dimension of the organizational communication between the managers and employees in the banking sector is analysed. The employees have given importance to participating in the decisions and being able to state their opinions about the job, and so the importance of communicative elements in forming the team work has been displayed. Providing a healthy working environment, tolerant and fair attitudes have been identified as the elements that affect the organizational communication of the employees. The results show that even though the differences about their gender, working hours at the bank, level of education, and education on communication do not differ much in participants' evaluating the communication problems between the manager and other bank employees, there are many differences in terms of age, status, and Professional status. Problems

Key Words: Banking Sector, Organizational Communication, Level of Perception to Communication

\footnotetext{
${ }^{1}$ Yrd. Doç. Dr., Fırat Üniversitesi, İiBF Fakültesi, İşletme Ana Bilim Dalı, ELAZIĞ. odemir@firat.edu.tr

${ }^{2}$ Frrat Üniversitesi, Sosyal Bilimleri Enstitüsü, Sağılı Kurumları Yöneticiliği Doktora Öğrencisi, ELAZIĞ. eray_ekin_1907@hotmail.com
} 


\section{GíRIŞ}

Günümüzde işletmecilik ve kurum kültüründe çok önemli bir yere sahip olan örgütsel iletişim, kurumun işleyişinin düzenli olmasının yanısıra kurumsal stratejileri hayata geçirilmesinin de önemli koşulları arasında yer almaktadır. Hizmet sektöründe kurumun sergilediği hizmetin kalitesi de rekabet açısından doğrudan bir önem arz etmektedir. Hizmet sektöründe faaliyet gösteren işletmelerin standartları yükseltmeleri, ulusal ya da uluslararası kalite sertifikasyonlarına sahip olabilmelerinin önemli bir koşulu çok iyi işleyen bir örgütsel iletişime sahip olmalarından geçtiği bilinen bir gerçektir.

Hizmet sektörünün önemli kuruluşları arasında yer alan bankalar için örgütsel iletişimin önemi yadsınamaz bir gerçektir. Bankacılık sektöründe örgüt içinde yönetim ve işgörenler arasında iyi çalışan bir örgütsel iletişim kanalı, çalışanlar ve yöneticilerin iş tatminine olumlu etki yapacak ve kurumun yapmış olduğu hizmetin standartlarının yükselmesine yol açacaktır. Bankacılık sektörünün, işlem trafiği, yoğunluğu ve yüz yüze iletişimin açık olmasının bu sektörde örgütsel iletişimin ne derece önemli ve gerekli olduğunu göz önüne sermektedir.

Çalışmamızın kurumsal yapısında bankacılık sektörünün çerçevesi çizilmiş olup, sonrasında örgütsel iletişim ve bu iletişimin önündeki engeller literatür yardımıyla açıklanmaya çalışılmıştır. Çalışmamızda, Elazığ ve Malatya illerinde faaliyet gösteren banka personellerine anket uygulanmıştır. Bu anketle çalışanların örgütsel iletişim seviyeleri istatistiksel sonuçlarla ortaya konulmaya çalışılmıştır.

\section{Bankacılık Sektörü}

Ülkemizde bankacılığının tarihsel gelişim süreci incelendiğinde, bankacılık sektörünün Türkiye' de yapısı ve gelişiminin, ekonomik gelişme, ekonominin genel yapısı ve performansından oldukça fazla etkilendiği görülmektedir (Atlı ve Demir, 2015:111). Özellikle 1980 yılında başlayan ve ekonomimizi radikal bir biçimde etkileyen süreç, doğal olarak bankaları da çok yakından etkilemiştir. Bu dönemde uygulanmaya başlanan serbest piyasa ekonomisi her sektörde olduğu gibi, "bir hizmet sektörü olan" bankacıllk sektöründe de kendini hissettirmiştir. Bugün ülkemizde faaliyet gösteren bankalar gerek mali yapıları, gerekse kurumsal yapıları itibariyle göz ardı edilemeyecek bir seviyeye ulaşmıştır. Gerçekleştirilen reformlar ve büyüme modelleri, bankacılık ürün ve hizmetlerinin çeşitlenmesine ve yenilenmesine, kurumsal altyapı gelişmelerinin hızlanmasına yol açmıştır (Arslan,2008:130).

Türk Bankacılık Sisteminde, bankaların kuruluş amaçlarına göre değişen ve kanunlarla şekillenen farklı faaliyet alanları söz konusudur. Bunlardan bazılarını sıralayacak olursak; bankalar eldeki paranın muhafaza edilebileceği güvenli bir yer sağlamak, tedavüldeki paranın toplanması ve ödenmesi işlemlerini yerine getirmek, Bağkur, S.S.K primi, vergi tahsil işlemlerini yapmak, elektrik, su, doğalgaz, PTT, ev kirası vb. işlemlerin tahsil ve tediyesini yapmakla görevlidir (Şakar, 2000: 20).

Türk Bankacılık sektöründe Eylül 2015 itibariyle; 34 adet mevduat, 13 adet Kalkınma Yatırım ve beş adet Katılım Bankasının yanında şube sayısı 12.330 adet ve personel sayısı 218.006 kişidir. Verilerin grafiksel dağılımı aşağıdaki şekiller de gösterilmektedir (BDDK, 2015:1): 


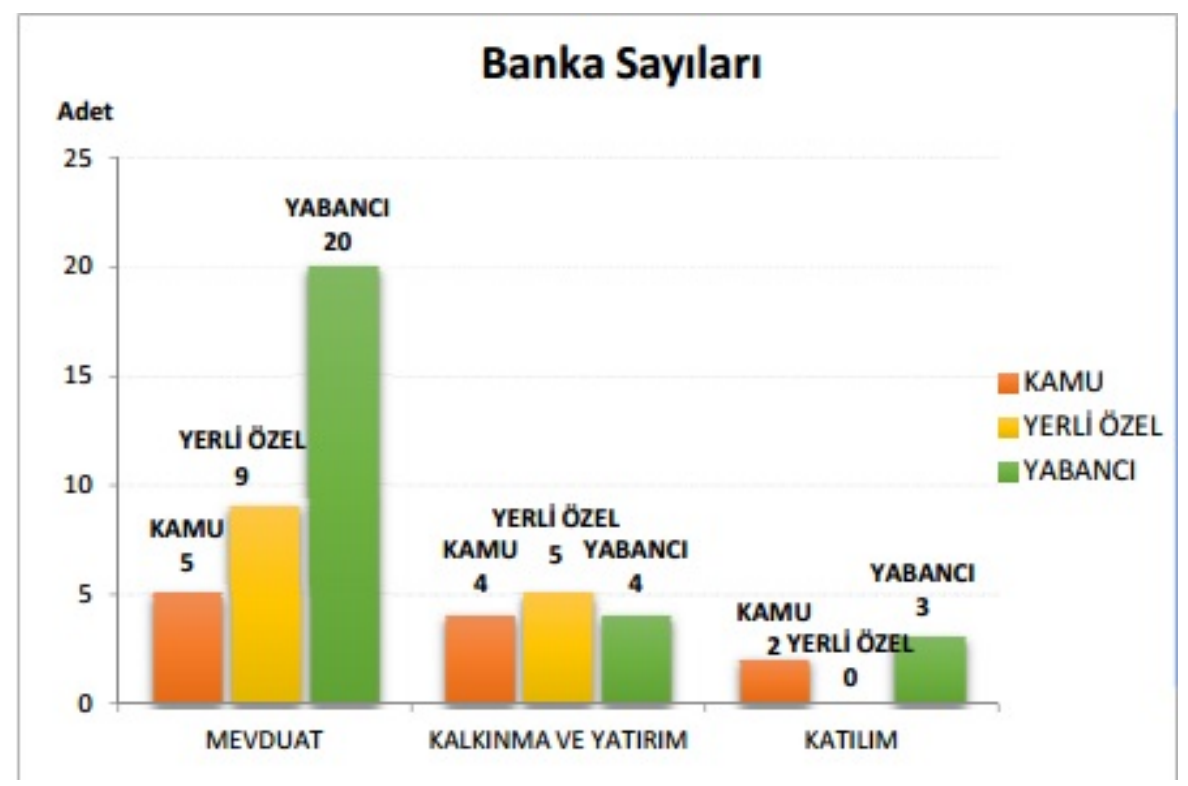

Şekil 1: Türk Bankacılık Sektörü Temel Göstergeleri-Banka Sayıları Kaynak: (BDDK, 2015:1)

Türk Bankacılık sektöründe Banka sayılarını bir önceki yıla göre (Eylül 2014) Mevduat Bankaları ve Katılım Bankalarında birer adet fazla olduğu görülmektedir. Bankacılık sektöründe mevduat bankalarının (kamu, özel ve yabancı bankalar) ağırlıkta olduğu görülmektedir.

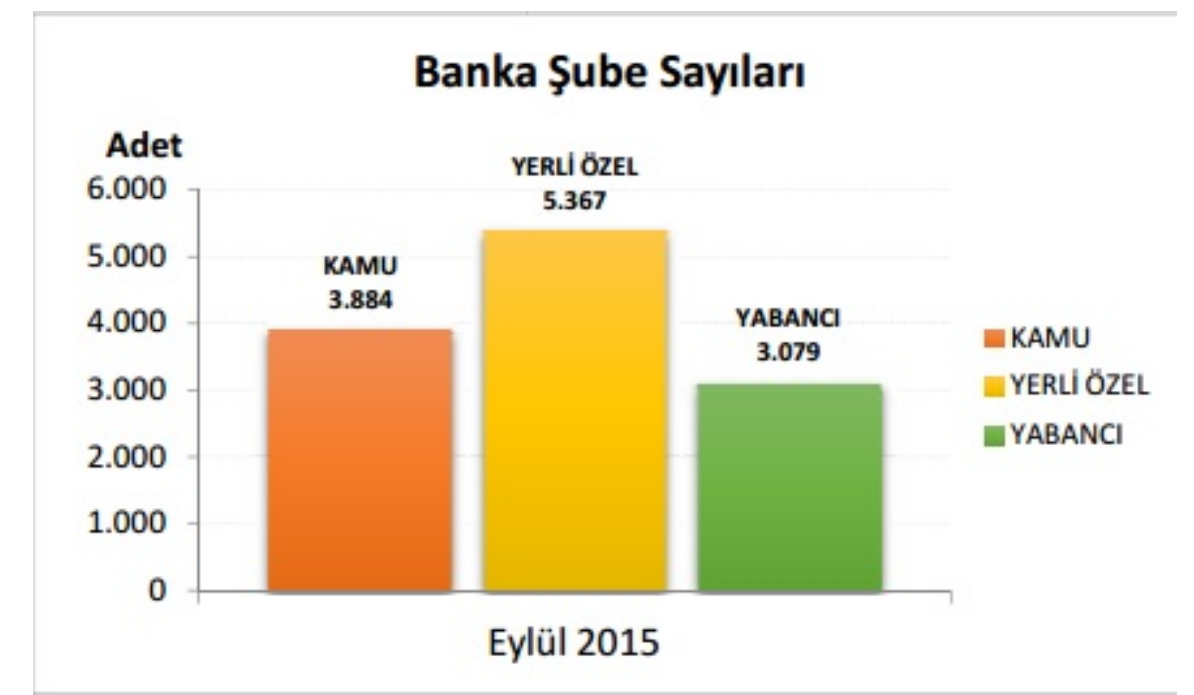

Şekil 2: Türk Bankacılık Sektörü Temel Göstergeleri-Banka Şube Sayıları Kaynak: (BDDK, 2015:1)

Şube sayılarının bir önceki yıla göre (Eylül 2014) gelişmesine bakıldığında, kamu bankalarının şube sayısının 405 adet arttığı, yerli özel banka şube sayılarının 352 adet azalış gösterdiği ve yabancı bankaların şube sayılarının ise 61 adet artış olduğu gözlenmiştir. Türk Bankacıllk sektöründe yerli özel bankalarının şube sayılarının liderlik göstergesi tüzel kişilerin bu sektörde fazla olduğunun ve daha fazla ekonomiye katkı yaptığının ispatı olarak karşımıza çıkmaktadır. Kamu ve özel banka şube sayılarının birbirine yakın olduğu görülmektedir. 


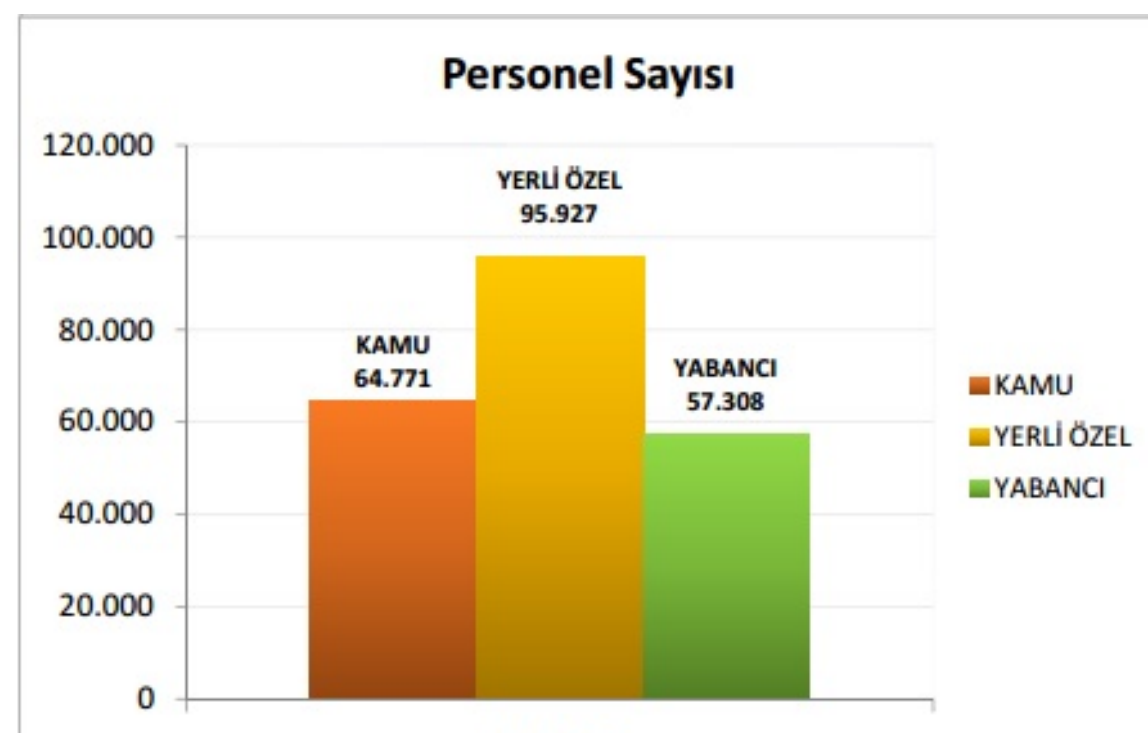

Eylül 15

Şekil 3: Türk Bankacılık Sektörü Temel Göstergeleri-Personel Sayıları Kaynak: (BDDK, 2015:1)

Ülkemizde ki bankacılık sektöründe personel sayısında bir önceki yıla göre (Eylül 2014) kamu bankalarında çalışan personel sayısının 6993 kişi arttığı, yerli özel bankada çalışan personel sayısının 5431 kişi azaldığı ve yabancı bankalarda çalışan personelin ise 726 kişi arttığ gözlenmiştir (bkz: Şekil 3). Yerli özel banka çalışanlarının bir önceki yıla nazaran personel sayısında azalış olsa da özel bankalar kamu ve yabancı banka çalışanlarına oranla daha fazla çalışan bulundurmaktadır.

\subsection{Bankacılık Hizmetleri}

Bankacılığın ortaya çıkışından bugüne kadar olan gelişmeler ve sunulan hizmetler geleneksel ve çağdaş bankacılık hizmetleri olmak üzere iki kısımda incelenebilir (Küçük,1993:28).

\subsubsection{Geleneksel Bankacilık Hizmetleri}

Bankaların geleneksel hizmetleri mevduat toplama, kredi verme ve bankacılık hizmetleri olmak üzere üç ana başlık altında toplanabilir (Oğuz, 2010: 34):

a) Mevduat Toplama: Bankalar, kişi ya da kurumların ellerinde atıl halde duran, gelir elde etme veya güvenli bir biçimde saklanmaları amaçlarıyla bankaya getirdikleri paraları toplayarak, istediklerinde ya da belli bir vadenin sonunda, belli bir bedel karş1lı̆g 1 geri ödeme hizmetini gerçekleştirirler.

b) Kredi verme: Bankacılıkta kredi, belli koşullarla kişilere ödünç verilmesi veya onların bu yükümlülükleri için garanti verilmesi anlamına gelmektedir. Bir kişiye kredi verilmekle ona hem mali bir olanak sağlanmakta, hem de ona saygınlık kazandırılmaktadır.

c) Bankacılık hizmetleri: Özellikle ticaret bankalarının fon toplama ve dağıtma işlevinin haricinde gerçekleştirdiği tüm faaliyetlerdir. Belli bir bedel karşıllı̆ında kişilere sunulan bu hizmetlerden en önemlileri akreditif, tahsil senetleri, havale, kiralık kasalar, menkul değerler ve repo hizmetleridir.

\subsection{2. Çağdaş Bankacılık Hizmetleri}

Son yıllarda bankacılık sektöründe teknolojik gelişmelerin de etkisiyle, sunulabilecek hizmet çeşitlerinde artışlar meydana gelmiştir. Telefon bankacılığ 1 , otomatik vezneler ve satış yerlerinde kredili alışveriş olanakları gibi uygulamalar bankacılığı 24 saate ve 365 güne yaymıştır (Uzkesici,1994:24). 


\section{a) Kredi Kartı}

Kredi kartı, kart hamiline açılmış bir potansiyel krediyi ifade eder (Yetim,1997:7). Bankaların haricinde, bazı kuruluşlar da kredi kartı hizmeti sunmaktadır. Bu kredi kartı kuruluşlarının bazıları uluslararası düzeyde faaliyette bulunur. Örneğin; Visa, Mastercard, Euracard, Dinners Clup kartlarını çıkartan kuruluşlar çok geniş bir ağa ve yüksek miktarda ciroya sahiptirler ve bankalar çoğu kez bu kuruluşlarla anlaşma yapmak suretiyle, bu kuruluşların kartlarını pazarlamaktadırlar (Küçük, 1993:29).

\section{b) Tüketici Kredileri}

Genel anlamda tüketici kredileri, herhangi bir hizmetin veya malın satın alımına bağlı olarak veya olmayarak ticari amaçlar dişında bireylere, sonradan belirli koşullarda geri ödenmek üzere verilen krediler olarak tanımlanabilir (Alpergin,1990:6).

\section{c) Menkul Kıymetler Hizmetleri}

Hazine bonosu, varlığa dayalı menkul kıymet, yatırım fonu alım satım işlemleri, repo gibi hizmetler sunulur.

\section{d) Satış Noktasından Elektronik Fon Transferi (EFT)}

Bir kart vasıtasıyla, terminallerden, müşterinin kendi banka hesaplarından, satıcının banka hesabına para aktarılması faaliyetleridir.

\section{e) Ev ve Ofis Bankacılı̆̆ı}

Ev ve ofis bankacılığında, müşterinin ev ofisindeki bilgisayar veya televizyonu, telefon ya da kablolu televizyon hatları aracılı̆̆ıla bankalara bağlanmakta ve müşteri bu yolla ev veya ofisinden hiç ayrılmadan banka hesabı üzerinden işlemler yapabilmektedir. Bu imkandan yararlanan müşteri menkul alım satımı yapmak, hesap durumunu öğrenmek, döviz alıp satmak, düzenli ödemelerini yapmak, kredi limitlerini öğrenmek gibi işlemlerini bankaya gitmeden gerçekleştirebilmektedir.

\section{f) Bilgi Danışma (Müşteri Temsilciliği) Hizmetleri}

Gerek müşteri odaklı bankacılık felsefesinin, gerekse halkla ilişkiler uygulamalarının uzantısı olarak gündeme gelmiş yeni bir bankacılık hizmetidir.

\subsection{Hizmet Sunan Personeller}

Bankalarda genel olarak mevcut bulunan pozisyonlar ve bu pozisyonların görev tanımları şu şekildedir (http://www.gundemim.net):

\section{Müfettiş Yardımcısı}

Müfettiş Yardımcısı pozisyonundaki çalışanlar Yönetim Kurulu adına, Genel Müdürlük Bölümlerinde, yurtiçi/yurtdışı şubelerde, Bankanın denetimi altındaki kuruluş ve işletmelerde, teftiş, soruşturma ve incelemeler yapmak gibi görevleri bulunmaktadır.

\section{Uzman Yardımcisı}

Uzman Yardımcısı pozisyonundaki çalışanlar, Genel Müdürlük Bölümlerinde ve Kurumsal Şubelerde, görev yaptığı birimin faaliyetlerini Banka mevzuatı çerçevesinde takip eder, uygular ve geliştirir. Yönetici adayı (MT) olarak yetiştirilen uzman yardımcıları, uzmanlık alanlarında aldıkları pek çok kurum içi ve dışı eğitimle çalışma alanlarında profesyonellik kazanırlar.

\section{Bilgi İşlem ve Yazılım Uzmanı}

Bilgi İşlem ve Yazılım Uzmanı pozisyonundaki çalışanlar, Bankanın günün koşullarına uygun altyapı ihtiyaçlarını ve hedeflerini ilgili birimlerle birlikte belirler, Bilgi Teknolojileri mimarisini tanımlar ve geliştirir, yönetim bilgi sistemleri ile iş zekâsı sistemlerini kurar, kurulan sistem ve alt 


\section{F.Ü. Sosyal Bilimler Dergisi 2017-27/1}

yapıların en etkin ve verimli şekilde işletimini, bakımını ve güvenliğini ilgili bölümlerle koordinasyon yaparak sağlar.

\section{Gişe Yetkilisi}

Gişe yetkilisi pozisyonundaki çalışanlar, Şube ve Genel Müdürlük Bölümlerinde temel bankacılık hizmeti ve bu hizmetlerin yerine getirilmesinde destek olan görevleri yerine getirir. Şubelerde gişe işlemleri ve operasyonel işlemlerde görev almanın yanısıra performanslarına ve bulundukları şubelerdeki kadro imkânlarına göre satış, kambiyo, sorunlu kredilerin takibi gibi alanlarda da görev yapabilir.

\section{Servis Yetkilileri}

Kredi, muhasebe gibi operasyon bölümlerinde işlemleri yönetip, yönlendiren görevli kişilerdir. İmza yetkisi gerektiren bu pozisyonlar için üstün performans göstermek veya sinavlarda başarılı olmak gerekmektedir.

\section{Satış ve Müşteri Temsilcileri}

$\mathrm{Bu}$ pozisyonda çalışan kişiler yoğun olarak kredi ve diğer ürünleri pazarlamak amacıyla doğrudan müşterilerle iletişim kurarlar. Satış performansına yönelik olarak şube içinde veya ağırlıklı olarak sahada görev alabilirler. Bu pozisyondaki çalışanların ikna kabiliyetinin yüksek olması beklenmektedir.

\section{Çağrı Merkezi Elemanı}

Bankaların Çağrı Merkezinde çağrı alma ve dış arama pozisyonlarındaki çalışanların kariyer yolu açık olup hem iletişim yetkinliklerini geliştirmekte hem de Bankacılıkla ilgili pek çok konuda derinlemesine bilgi sahibi olmaktadır. Bazı bankalarda işe giriş tarihlerini takip eden 2 yılın sonunda Şube veya Genel Müdürlük Bölümlerine nakil talebinde bulunmaya hak kazanırlar.

\section{Operasyon Elemanı}

Operasyon Elemanı pozisyonundaki çalışanlar, Şube ve Genel Müdürlük Bölümlerindeki operasyonel faaliyetlerde görev alarak, veri girişi, kontrol, yazışma vb. işlerde Banka süreçlerini desteklerler.

\section{Takip Yetkilisi}

Bankaların hukuk müşavirliği ve müşavirliğe bağlı bölge teşkilatında; hukuksal işlemlerin iç ve dış evrak takibini yapar; noter, adliye, ticaret odası, tapu daireleri ve diğer kamu kuruluşları ile ilgili işleri yürütürler. Takip yetkilisi kariyer yolu kapalı bir pozisyondur.

\section{İhtisas Elemanı}

Avukat, mimar, mühendis gibi pozisyonlarda istihdam edilen çalı̧̧anlardır.

\section{Özel Güvenlik Görevlisi}

Özel Güvenlik Görevlisi pozisyonundaki çalışanlar Şubelerde ve Genel Müdürlüklerde silahlı özel güvenlik görevini yerine getirir.

\section{Şoför}

Makam şoförü ve para nakil aracı şoförü olarak istihdam edilen çalışanlardır.

\section{2. Örgütsel İletişim Tanımı ve Önemi}

İletişim, insanların davranışlarını etkilemek ya da belli bir sonuca ulaşmak amacıyla, duygu, düşünce, inanç, tutum ve davranışlarını sözlü, yazılı ya da sözsüz olarak iletmeleridir (Demirtaş, 2010:413). Daha öz bir şekilde iletişim, bilgi üretme, aktarma ve anlamlandırma sürecidir (Yatkın ve Yatkın, 2015:40). Söz konusu süreç kişiler arası ilişkinin her türünü, örgütleri ve toplumları yaratıp bir arada tutan bir harç işlevi görmektedir. 
Ortak bir amacı gerçekleştirmek için bir araya gelen bireyler, gruplar, topluluklar ve örgütler için iletişim hayati bir öneme sahiptir. Örgütteki bireyler ve gruplar arasında olması gereken uygun etkileşimi sağlayan öğe ise örgütsel iletişimdir (Durğun,2006:119-120). Örgütsel iletişim, örgütlerde yöneticilerin eşgüdüm ve ilişkileri koordine etme gibi yönetim fonksiyonlarının işletilmesi süreçlerindeki simgelerin üretilmesi, paylaşılması, yorumlanması ve anlamlandırılmasıdır (Ayık ve Fidan,2014:110). Daha genel bir tanımla örgüt iletişimi, örgütün biçimsel ve biçimsel olamayan grupları arasında kurulan iletişimdir. Örgüt iletişimi, örgüt üyelerinin "örgütsel amaçlarla", örgütün içinde ve örgütün dışında kurdukları iletişim biçimidir (Ulukuş, 2010:36).

Örgütsel iletişim algılamalarına yönelik yaklaşımlar ve tanımlar pek çoktur. Bir yazar örgütsel iletişimden hangi anlamı çıkarmak ve onu nasıl anlamak istiyorsa öyle anlayabilir. Çok farklı görüşler olmasına rağmen birkaç ortak nokta pek çok anlayışın içinden tespit edilebilir. Bunlar;

Örgütsel iletişim; içsel ve dışsal çevrenin her ikisi tarafından da etkilenen ve bu çevrelerin her ikisini de etkileyen birden çok ögeden oluşan açık bir sistemde ortaya çıkar.

$>\quad$ Örgütsel iletişim mesajları ve onların akısını, amacını, yönünü ve aracını içerir.

$>\quad$ Örgütsel iletişim insanları ve onların tutumlarını, duygularını, ilişkilerini ve becerilerini kapsar.

Bu önermeler şekil 4'de görülmektedir (Yüksel, 2007:22-23).

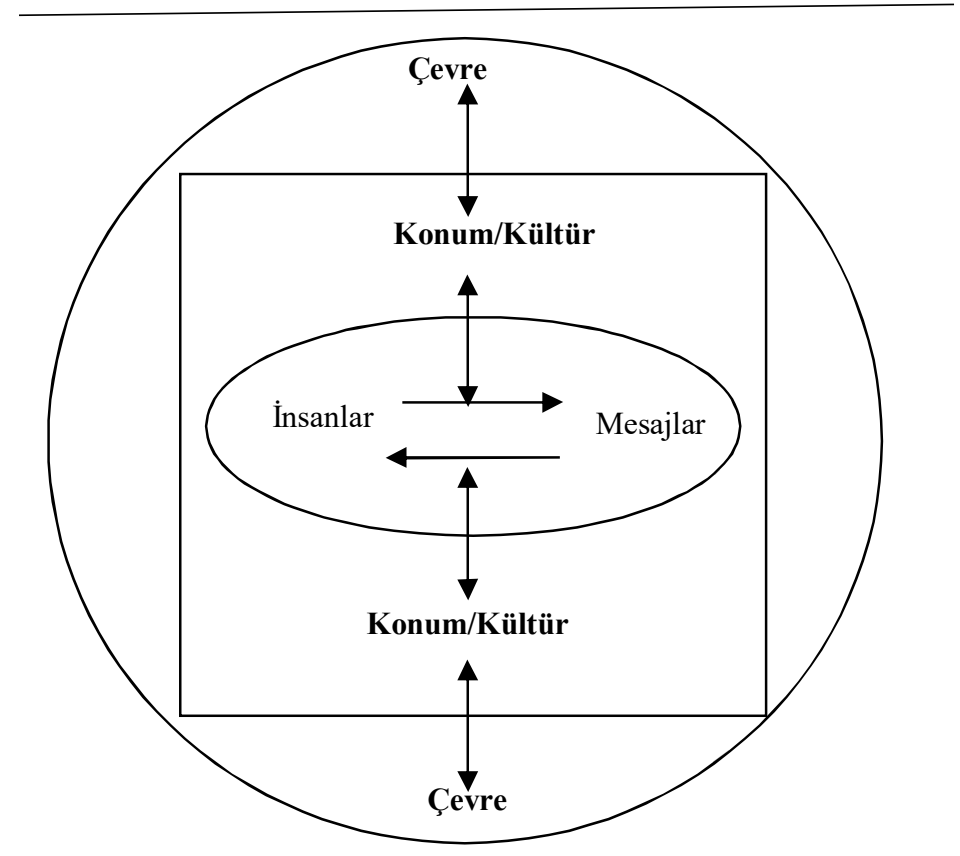

Şekil 4: Örgütsel İletişim Modeli

Kaynak: Yüksel, 2007:23

Örgütün amaçlarını gerçekleştirmesi, örgütün işlerlik kazanması, içinde bulunduğu toplumsal yapının bir parçası olarak diğer birimlerle düzenli ilişkiler kurması ancak iletişim süreciyle gerçekleşebilir. Etkili bir örgütsel iletişim, biçimsel örgüt yapısını güçlendirecek; bireylerin psikolojik ihtiyaçlarını giderecek; örgüte bağlılık duygularını artırmanın yanında, motivasyon sağlayacak ve dolayısıyla iş verimliliğini arttıracaktır.

Örgütteki tüm öğelerin, örgütsel amaçlar doğrultusunda etkileşimde bulunması iletişimin etkinliğine bağlı bulunmaktadır. İletişim bu bağlamda işlerin koordine edilmesinde, örgütsel problemlerin çözümünde, bilgi paylaşımının sağlıklı ve yaygınlık kazanması ve çatışmaların çözümünde oldukça önemli bir yere sahiptir (Demirel vd, 2011:36). 


\section{F.Ü. Sosyal Bilimler Dergisi 2017-27/1}

\subsection{Bankacılık Sektöründe İletişim Engelleri}

Banka yöneticisi, iletişimin sağlıklı yürüyebilmesi amacıyla, hem akılcı kararlar vererek iletişim ortamını düzenlemek, iletişimin bozulması durumunda alınacak tedbirleri, doğal iletişim kanallarını kullanarak, eğitim ve statü farklılıklarından kaynaklanan kopuklukları işletme içindeki doğal gruplarla işbirliği içinde bulunarak çözmeye çalışacaktır (Kaya,1992:132).

İletişim süreci, günlük yaşamda çeşitli faktörlerin de etkisiyle kesintiye uğramaktadır. Çoğunlukla iletişim sonunda beni yanlış anladın, ben aslında öyle demek istememiştim sözlerinin dilimizden döküldügünü görürüz. İletişism sürecinde yaşanan iletişim engellerini; Kişisel engeller, teknik engeller ve örgütsel engeller olmak üzere üç alt başlık da incelemek mümkündür.

\subsubsection{Kişisel Engeller}

Banka kurumlarında iletişimi etkileyen engeller içinde en önemli olanı kişisel faktörlerle ilgili olanıdır. Kişisel faktörler hem yönetici hem yönetilenler açısından ele alınabilir. Buna göre kişisel faktörleri şöyle sıralayabiliriz (Sağbaş,2013:49-50):

- Çalışanlar, yöneticilerinin sadece hoşuna giden bilgileri vermek amacıyla mesajı süzmeleri,

- Mesaj1 alan ve yorumlayan kişinin eğitim ve kültür düzeyi,

- Mesajı alan ve yorumlayan kişinin sahip olduğu değer, inanç, kültür düzeyi,

- Mesajı gönderen kişi, alıcıya göre güvenilmeyen bir kişi ise, mesajın alınma düzeyi istenenle aynı olmayacaktır.

İletişimde güvenilirlik çok önemlidir. Banka kurumlarında iletişimle ilgili kazaların en aza indirilmesi için çalışma ortamındaki güven duygusunun en aza indirilmesi gerekir. Güvenin temelinde de hareket ve sözlerdeki dürüstlük önemli yer tutmaktadır.

\subsubsection{Teknik Engeller}

İletişimde karşılaşılan teknik sorunları aşağıda belirtildiği gibi sıralamak mümkündür (Sağbaş,2013:50-51):

- Banka kurumlarında iletişim açısından önemli bir teknik engel konuşma ve yazı dilindeki karışıklıklardan kaynaklanan farklar ve anlaşmazlıklardır.

- Dil haberleşme araçları içinden önemli olanıdır. Bazen kullanılan kelimelerin birden fazla anlamı vardır ve bu anlamlar cümle içinde bulunduğu yere göre değişebilir. Kaynağın bir kelime ya da kavrama verdiği anlam ile mesajı alan kişinin kavrama verdiği anlam farklı olabilir.

- İletilen mesajların değişikliğe uğramasına ya da kastedilen anlamdan farklı bir anlama bürünerek sapmasına gürültü adı verilir. Gürültü, kalabalık bir ortamdaki insan çokluğundan kaynaklanabileceği gibi, dinleyicinin kafasının başka şeylerle meşgul olması gibi psikolojik kaynaklı da olabilir. İletişim sürecinde "gürültü" olarak adlandırılan bu tür olaylar, dışsal kaynaklıdır ve özellikle yöneticilerden gelen mesajların etkili, eksiksiz olarak algılanmasını önlerler. İletişim sürecinin işletildiği esnada dış etmenler iyi hesaplanmalı, iletişimin insanlar üzerinde beklenen etkiyi sağlayabilmesi için uygun ortamlar aranmalıdır.

- Yazıda kullanılan birtakım kısaltmalar, uzun cümleler kurulması ve noktalama işaretlerine, vurgu ve tonlamalara dikkat edilmeden konuşulması, iletişim açısından önemlidir. Ayrıca, her meslek veya ilim kolu kendine göre kelime hazinesine sahiptir. Meslek ne kadar eski ise o meslekte kullanılan kelime ve terimler de o oranda fazladır. Buna karşılık, teknolojik ilerlemenin doğurduğu yeni meslek dallarıyla ilgili çalışmaların ifade edilmesi sürecinde sıkıntıların yaşanacağ düşünülebilir. 


\subsection{3. Örgütsel Engeller}

Yerel uzaklık ve hiyerarşik yapının fazla olması, örgütün bütününde olması gereken iletişimi olumsuz yönde etkileyebilmektedir. Örgütsel yapıdan kaynaklanan bazı engeller şöyledir (Sağbaş,2013:51-52):

- Kaynak ve alıcının statüleri, akademik ve mesleki gelişme farkları, bir mesajın gönderildiği yer ve zaman, iletişimin kalitesini etkiler. Kötü yer ve zaman seçimi, mesajın içeriğinde kayıpla sonuçlanacaktır. Mesaj iletiminde gecikmelerin olması ya da zamanından önce bilgilerin iletilmesi mesajın etkili şekilde ve doğru olarak iletilmesini önemli ölçüde değiştirir

- Örgütler büyüdükçe, iletişim güçleşir, merkezden yönetim azalır, gecikmeler, karmaşıklık, bürokrasi artar bu da iletişimin kalitesini etkiler.

- Yoğun şekilde mesaj alışverişinin olması, yöneticinin yoğun bilginin altında ezilmesi ve gelen mesajlara cevap veremez hale gelmesi ile iletişimde bozulmalar başlar. Aşırı bilgi yükleme, göndericinin belli bir zamanda alıcıya gerektiğinden fazla ileti göndermesidir. Kişinin sahip olduğu kapasite aşı1ırsa iletişim amacına ulaşamaz.

- İşletmelerde gereğinden fazla çalışan bulundurulması, işletmede yapılacak işlerin iyi düzenlenememesi ve bu işleri yapacak kişilerin sorumluluklarının belirlenememesi ve görev tanımlarının çizilememesi, işlerin gelişmesiyle oluşturulan yeni birimlerin ilgili bölümlere bağlanmamasından ileri gelebilir. Örgütlerde fazla sayıda çalışan bulundurulması, kullanılacak iletişim kanallarının sayısını artırır. Kanal sayısının artması, yazılı ve sözlü iletişimin içeriğinde olumsuz etkiler meydana getirebilir.

- Örgütlerde yönetim kademelerinin ve bu kademelerde görevli yöneticilerin sayısının artması, iletişim sürecinde iletilen mesajın içeriğinde değişmelere yol açacaktır.

\section{ARASTIRMA İLE İLGİLI ÖN BİLGILER VE BULGULARIN DEĞERLENDİRİLMESİ}

\subsection{Araştırmanın Amacı}

$\mathrm{Bu}$ çalışmanın temel amacı, bankalarda ki yönetici ve çalışanların iletişim sorunlarına yönelik algilarını ortaya koymaktır.

\subsection{Araştırmanın Sağlayacağı Katkılar}

İletişim konusu, yerli ve yabancı literatürde gereken önemin verildiği, örgütler ve çalışanlar açısından oldukça önem arz eden bir konudur. Kısacası iletişim, toplumsal yaşam için ne kadar gerekli ve kaçınılmaz ise örgütsel yaşam içinde aynı derecede kaçınılmaz vazgeçilmezdir.

İletişim ve iletişim kaynaklı engeller ile ilgili birçok araştırmaya literatürde rastlanmaktadır. Konuya farklı yönlerle yaklaşan çalışmaların varlığına rağmen kurum ve il açısından bakacak olursak özellikle Elazığ ve Malatya illerinde faaliyet gösteren banka kurumlarında yapılıyor olması bu çalışmayı farklı kılmaktadır.

İşletme alanında iletişim alanına giren öncül çalışmalardan olması bu çalışmanın özgün yanına ilişkin işaretlerdendir. Böylelikle ilgili bir literatür tabanı oluşacak ve ilerisi için akademisyenlere esin kaynağı olacak yeni bir bakış açısı meydana getirilecektir.

\subsection{Araştırmanın Yöntemi}

Araştırma teorik çerçeve ile desteklenmiş bir tanımlayıcı araştırma niteliğindedir. Araştırma kapsamında söz konusu Elazığ ve Malatya illerindeki özel ve kamu banka çalışanlarına nicel araştırma yaklaşımı kullanılarak; deneysel bir araştırma yapılmış ve çalışmanın sorularına yanıt verebilmek amacıyla veriler anket yöntemiyle toplanmıștır. Ankette demografik bilgilerin yanı sıra iletişim sorunlarına yönelik ölçekler yer almaktadır. Anket tekniğinin seçilmesinin nedeni geniş bir gruptan, çok miktarda veriyi kısa zamanda kolayca toplama imkanını vermesidir. 


\section{F.Ü. Sosyal Bilimler Dergisi 2017-27/1}

\subsection{Evren ve Örneklem}

Araştırma evrenini Elazı̆̆ ve Malatya illerindeki 20 bankaya ait 39 Şubede çalışan 790 kişi ana kütleyi oluşturmaktadır. Ana kütlenin tamamına ulaşılmaya çalışılmış ve bu yönde tüm banka şubelerine 790 anket formu bırakılmıştır. İş yerinde olmayanlar ve ankete katılmayanlar nedeniyle 272 anket formu geri toplanabilmiştir. Elde edilebilen anket formlarından yanlış ve eksik doldurma nedeniyle 45 tanesi değerlendirmeye alınmamıştır. Bu nedenle, analizler 227 anketten elde edilen veriler üzerinden gerçekleştirilmiştir.

\subsection{Veri Toplama ve Analiz Teknikleri}

Anket formu iki kısımdan oluşmaktadır. İlk kısımda, katılımcıların demografik özelliklerini belirlemeyi amaçlayan 7 soru yer almaktadır. İkinci kısımda, Yönetici ve Diğer Banka Çalışanları Arasındaki İletişim Sorunlarına yönelik 25 soru yer almaktadır.

Ölçekler, 5'li Likert tipindedir. İletişim sorunlarına yönelik ölçekte ki seçenekler 1'den 5'e doğru ' Hiçbir zaman, Nadiren, Bazen, Çoğu zaman, Her zaman', şeklinde sıralanmaktadır.

Verilerin analizi için frekans dağılımı, aritmetik ortalama, standart sapma, parametrik olmayan test tekniklerinden (Mann Whitney U-Testi, Kruskal Wallis H-Testi) yararlanılmıştır. Söz konusu analizler, SPSS paket programı aracılı̆̆ıyla gerçekleştirilmiştir.

\subsection{Faktör Analizi Sonuçları ve Güvenilirlik Analizi}

Ölçeğin yapı geçerliğini istatistiksel olarak tespit etmek için açıklayıcı faktör analizi tekniği kullanılmıştır. Faktör analizinin yapılıp yapılamayacağının belirlenmesi için KMO ve Bartlett testleri yapılmıştır. Bunun sonucuna göre KMO değer 0,967 , Bartlett değeri de $(P<0,05)$ anlamlı bulunmuştur. Buna göre ölçeğin faktör analizi yapılabileceği sonucuna ulaşılmıştır. Bu değerler Tablo 1'de gösterilmektedir.

Tablo 4. Faktör Analizi Sonuç Raporu-KMO ve Barlett's Test Tablosu

\begin{tabular}{|l|l|l|}
\hline \multicolumn{2}{|l|}{ Kaiser-Meyer-Olkin Measure of Sampling Adequacy. } & 0,967 \\
\hline \multirow{3}{*}{ Bartlett's Test of Sphericity } & $X 2$ & $5,690,400$ \\
\cline { 2 - 3 } & $\mathrm{sd}$ & 300 \\
\cline { 2 - 3 } & $\mathrm{p}$ & $0,000^{* *}$ \\
\hline${ }_{\mathrm{p}}<0.05$ &
\end{tabular}

Güvenirlik analizi kullanılan yöntemlerden bir tanesi ve en yaygın olarak kullanılanı Cronbach's Alfa katsayısıdır. Çalışmada elde edilen alfa katsayısı 0.974'tir. Bu durum güvenirlik düzeyinin çok yüksek olduğunu göstermektedir.

\subsection{Tanımlayıcı Analiz Sonuçları}

Katılımcılara ilişkin demografik veriler, frekans analizleri ile incelenmiştir. Elde edilen bulgular sırasıyla sunulmaktadır. Katılımcıların cinsiyet, yaş, görevi, statü, bankadaki çalışma süresi, öğrenim durumu, iletişim ile ilgili eğitim alıp almama durumu dağılımı Tablo 2'de gösterilmektedir. 
Bankacıllk Sektöründe Örgütsel İletişim Kaynakl Sorunların...

Tablo 2. Kişisel Bilgiler, Katılımcıların Demografik Özelliklerine Göre Dağılımı

\begin{tabular}{|c|c|c|c|}
\hline & & $\mathbf{F}$ & $\%$ \\
\hline \multirow{2}{*}{ Cinsiyet } & Erkek & 115 & 51 \\
\hline & Kadın & 112 & 49 \\
\hline \multirow{7}{*}{ Yaş } & 25 ve alt1 & 30 & 13,2 \\
\hline & $25-30$ & 35 & 15,4 \\
\hline & $30-35$ & 54 & 23,8 \\
\hline & $35-40$ & 35 & 15,4 \\
\hline & $40-45$ & 30 & 13,3 \\
\hline & $45-50$ & 24 & 10,5 \\
\hline & 50 ve üzeri & 19 & 8,4 \\
\hline \multirow{5}{*}{ Görevi } & Servis Memuru & 36 & 15,8 \\
\hline & Gişe Görevlisi & 145 & 64,0 \\
\hline & Şube Müdürü & 8 & 3,5 \\
\hline & Müdür Yardımcısı & 10 & 4,4 \\
\hline & Müşteri İlişkileri ve Satış Danışmanı & 28 & 12,3 \\
\hline \multirow{2}{*}{ Statü } & Yönetici & 36 & 15,8 \\
\hline & Diğer & 191 & 84,2 \\
\hline \multirow{5}{*}{ Bankadaki Çalışma Süresi } & $0-5$ y1l & 51 & 22,4 \\
\hline & $5-10$ & 76 & 33,4 \\
\hline & $10-15$ & 52 & 23 \\
\hline & $15-20$ & 30 & 13,2 \\
\hline & 20 ve üzeri & 18 & 8 \\
\hline \multirow{5}{*}{ Öğrenim Durumu } & Lise & 29 & 12,8 \\
\hline & Ön Lisans & 80 & 35,2 \\
\hline & Lisans & 98 & 43,1 \\
\hline & Yüksek Lisans & 18 & 8 \\
\hline & Doktora & 2 & 0,9 \\
\hline \multirow{2}{*}{$\begin{array}{l}\text { İletişim ile ilgili eğitim alıp } \\
\text { almama }\end{array}$} & Evet & 118 & 51,9 \\
\hline & Hayır & 109 & 48,1 \\
\hline
\end{tabular}

Çalışmaya katılan banka çalışanlarının \%49'u kadın, \%50'si erkektir.

Çalışmaya katılan banka çalışanlarının çoğunluğunu \%23,8 ile 30-35 yaş grubu çalışanlar oluşturmaktadır. En az ise \%8,4 ile 50 ve üzeri yaş grubu çalışanlar oluşmaktadır.

Çalışmaya katılan banka çalışanlarının çoğunluğunu gişe görevlileri ve en az katılımı ise şube müdürü ve müdür yardımcısı çalışanları oluşturmaktadır. Bunun nedeni bankalarda her birimde bir kök oluşturan ve müşteri yoğunluğunu karşılayan gişe görevlilerinin olması gerekliliğinden kaynaklanmaktadır.

Çalışmaya katılan banka çalışanları arasında yöneticilerin sayısı diğer banka çalışanlarından daha azdır. Bunun nedeni bankacılık kurumunda çalışan yöneticilerin sayısının diğer çalışanlara göre daha az olmasından kaynaklanmaktadır.

Çalışmaya katılan banka çalışanlarının bankada çalışma süresi çoğunluğunu \%33,4 ile 5-10 yıl arası çalışanlar oluşturmaktadır ve en az süreyi $\% 8$ ile 20 ve üzeri yıl çalışanlardır.

Çalışmaya katılan banka çalışanlarının öğrenim durumuna bakıldığında \%12,8'inin lise, $\% 35,2$ 'inin ön lisans, \%43,1'inin lisans, \%8'inin yüksek lisans ve \%0.9'unun doktora mezunu olduğu görülmektedir. 


\section{F.Ü. Sosyal Bilimler Dergisi 2017-27/1}

Çalışmaya katılan banka çalışanlarının çoğunluğunu daha önce iletişim ile ilgili eğitim alanlardan oluştuğu görülmektedir. Bunun nedeni ise kurumda hizmet içi eğitimlerin verilmesinden kaynaklanmaktadır.

\subsection{Banka Kurumlarında Çalışan Yönetici ve Diğer Banka Personeli Arasındaki İletişim Sorunlarına Yönelik İfadelere Katılım Düzeylerinin Analizi}

Banka kurumlarında çalışan yönetici ve diğer banka personeli arasında iletişim sorunlarına yönelik ifadelerine ilişkin frekans değerleri tablo 3'de gösterilmektedir. Buna göre her bir ifadeye katılım sıklığı incelenerek yüzdesel değerler, ifadelere katılım ortalamaları ve standart sapma değerleri analiz edilmiş ve yorumlanmıştır.

Tablo 3. Yönetici ve Diğer Banka Çalışanları Arasındaki İletişim Sorunları İfadelerine Verilen Cevapların Dağılımları

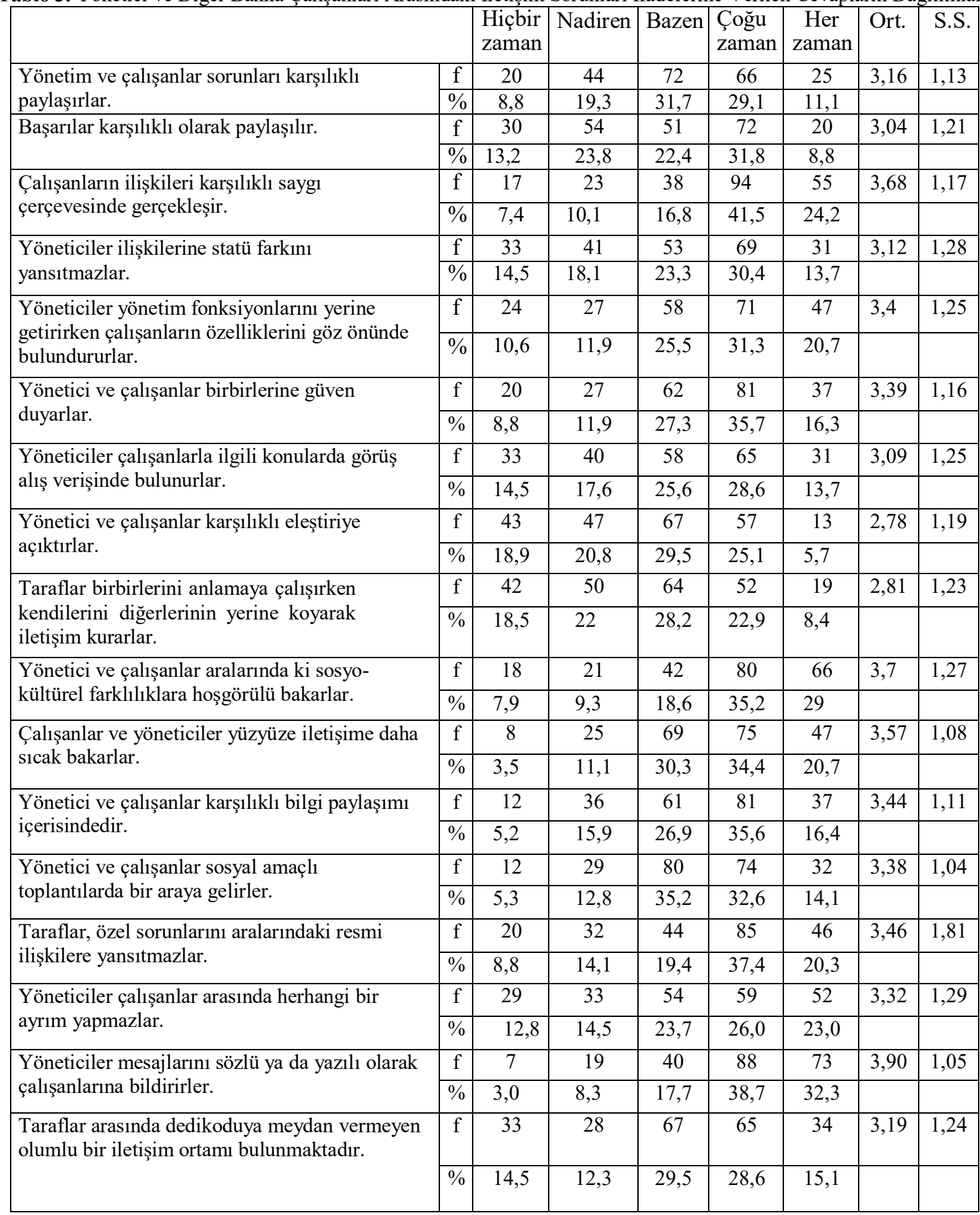


Bankacıllk Sektöründe Örgütsel İletişsim Kaynakl Sorunları...

\begin{tabular}{|c|c|c|c|c|c|c|c|c|}
\hline \multirow{2}{*}{$\begin{array}{l}\text { Banka şubesi ile ilgili kararlarda taraflar } \\
\text { birlikte ortaklaşa hareket ederler. }\end{array}$} & $f$ & 45 & 43 & 70 & 48 & 21 & 2,81 & 1,23 \\
\hline & $\%$ & 19,9 & 18,9 & 30,8 & 21,2 & 9,2 & & \\
\hline \multirow{2}{*}{$\begin{array}{l}\text { Yöneticiler banka çalışanları arasında sağlıklı bir } \\
\text { iletişim ortamı oluştururlar. }\end{array}$} & $\mathrm{f}$ & 21 & 38 & 62 & 69 & 37 & 3,29 & 1,16 \\
\hline & $\%$ & 9,2 & 16,8 & 27,3 & 30,3 & 16,4 & & \\
\hline \multirow{2}{*}{$\begin{array}{l}\text { Yöneticiler çalışanları dayanışmaya teşvik } \\
\text { ederler. }\end{array}$} & $f$ & 24 & 34 & 59 & 67 & 43 & 3,32 & 1,22 \\
\hline & $\%$ & 10,6 & 14,9 & 25,9 & 29,7 & 18,9 & & \\
\hline \multirow{2}{*}{$\begin{array}{l}\text { Bankada taraflar arasında formel ve informel } \\
\text { iletişim kanalları da bulunmaktadır. }\end{array}$} & $\mathrm{f}$ & 11 & 41 & 59 & 82 & 34 & 3,39 & 1,09 \\
\hline & \% & 4,8 & 18,2 & 26,0 & 36,1 & 14,9 & & \\
\hline \multirow{2}{*}{$\begin{array}{l}\text { Taraflar aralarında etkin iletişimi sürdürme } \\
\text { konusunda içten bir çaba gösterirler. }\end{array}$} & $\mathrm{f}$ & 30 & 40 & 57 & 66 & 34 & 3,16 & 1,24 \\
\hline & $\begin{array}{l}\% \\
\end{array}$ & 13,4 & 17,6 & 25,1 & 29,0 & 14,9 & & \\
\hline \multirow{2}{*}{$\begin{array}{l}\text { Taraflar iş yaşamı ve çalışma ortamını } \\
\text { aynı şekilde algılar ve yorumlar. }\end{array}$} & $\mathrm{f}$ & 13 & 33 & 76 & 71 & 34 & 3,37 & 1,07 \\
\hline & $\%$ & 5,7 & 14,5 & 33,5 & 31,2 & 15,1 & & \\
\hline \multirow{2}{*}{$\begin{array}{l}\text { Taraflar iletişimde karşılıklı olumlu } \\
\text { hareketlerini ön plana çıarırlar. }\end{array}$} & $f$ & 25 & 32 & 60 & 74 & 36 & 3,31 & 1,23 \\
\hline & \% & 11,0 & 14,1 & 26,4 & 32,6 & 15,9 & & \\
\hline \multirow{2}{*}{$\begin{array}{l}\text { Taraflar aralarındaki iletişimde aynı } \\
\text { zamanda iyi birer dinleyici } \\
\text { durumundadırlar. }\end{array}$} & $\mathrm{f}$ & 25 & 37 & 51 & 68 & 46 & 3,33 & 1,19 \\
\hline & $\%$ & 11,1 & 16,3 & 22,4 & 30,0 & 20,2 & & \\
\hline
\end{tabular}

Banka Kurumlarında Çalışan Yönetici ve Diğer Banka Personeli Arasındaki İletişim Sorunlarına Yönelik İfadeler, tablo 3'de sunulan önermelerle incelenmeye çalışılmıştır. Anketimizi yanıtlayanlar, önermelerimizim büyük çoğunluğuna üçün üzerinde yer alan değerlerle katıldıklarını ifade etmişlerdir.

Yönetici ve banka çalışanları arasındaki iletişim sorunlarına yönelik ifadeler incelendiğinde en sıklıkla katılım oranı 3,90 ile "Yöneticiler mesajlarını sözlü ya da yazılı olarak çalışanlarına bildirirler" ifadesidir. İşlerin doğru ve zamanında yürümesi sağlanır. Buna karşın en az sıklıkla katılım ise 2,78 oran ile "Yönetici ve çalışanlar karşılıklı eleştiriye açıktırlar" ifadesidir. Yönetici ve çalışanlar birbirlerine karşı eleştiriye açık olmamaları aralarındaki iletişimi olumsuz etkilemektedir. $\mathrm{Bu}$ durumda yöneticilerin katıldıkları bilgilendirme çalışmaları daha üst makamlarca düzenlenmelidir. Yönetici; eleştiriye açık, hoşgörülü, çalışanlara saygıll, becerikli, yeterli, empatik, konuya hakim olmalı ve kişisel egolardan sıyrılmalıdır. Yönetici olmanın getirdiği sorumlulukla başa çıkmakta zorlananlar için bu tür eğitim programları fayda sağlayacaktır.

"Yönetici ve çalışanlar aralarında ki sosyo-kültürel farklılıklara hoşgörülü bakarlar" ifadesi 3,70 'lik oran ile yüksek sıklıkla katılım gösteren bir ifadedir. Bu ifadenin yüksek sıklıkla katılım göstermesi çalışanların özel hayatlarına müdahale edilmediği ve çalışanların görüşleriyle yargılanmadığını göstermektedir.

"Yönetici ve çalışanlar karşı1ıklı bilgi paylaşımı içerisindedir" ifadesi 3,44'lük oranı ile orta sıklıkla katılım gösteren bir ifadedir. Yönetici ve çalışanların bilgilerini karş1lıklı olarak paylaşmamaları iletişimin sağlıklı bir şekilde ilerlemesini engelleyecektir. Yönetici ve çalışanların bilgilerini gönüllü olarak paylaşması iletişim sürecini olumlu yönde etkileyecektir.

'Taraflar birbirlerini anlamaya çalışırken kendilerini diğerlerinin yerine koyarak iletişim kurarlar" önermesi 2,81'lik oranı ile orta sıklıkla katılım gösteren bir ifadedir. Fakat en düşük ifade olan eleştiriye açık olurlar ifadesinden sonra düşük olan ifadelerden biride budur. Katılım derecesinin düşük seyirde olmasının nedeni empatinin banka çalışanları arasında ya da yönetici ve çalışanlar arasında çok iyi olmadığını göstermektedir.

'Taraflar iletişimde karşılıklı olumlu hareketlerini ön plana çıkarırlar" önermesi 3,31'lik oranı ile orta sıklıkla katılım gösteren bir ifadedir. Yöneticiler, çalışanlarla aralarındaki iletişim sürecini pekiştirmek için birbirlerinin olumlu davranışlarını öne çıkarmak ve takdir etmelidirler. 


\section{F.Ü. Sosyal Bilimler Dergisi 2017-27/1}

"Taraflar aynı zamanda iyi birer dinleyici durumundadırlar", önermesi 3,33'lük oranı ile yine orta sıklıkla katılım gösteren bir ifadedir. Yönetici ve çalışanlar arasındaki iletişimin etkili ve verimli olabilmesi için her iki tarafinda birbirini dinlemeleri ve anlamaları gerekmektedir.

Yöneticiler ve diğer banka çalışanları arasındaki iletişim sorunları ile ilişkin olarak yapılan bu analizde orta sıkl1kta katılım gösteren ifadelerin fazla olduğu görülmektedir. Bunun sonucunda yönetici ve çalışanlar arasında yeterince etkili ve sağlıklı bir iletişim olmadığı sonucu ortaya çıkmaktadır. Bunun için yönetici ve çalışanlar aralarında empati kurarak ve birbirlerini anlamaya çalışarak etkili ve açık bir iletişim kurmaya çalışmalıdırlar. Ayrıca başarılı olabilmeleri için etkili ve sağlıklı bir iletişim ortamı kurmak önemli olacaktır.

\subsection{Yönetici ve Bankadaki Diğer Çalışanlar Arasındaki İletişim Sorunlarının Demografik Özelliklere Göre Analizi}

Yapılan normallik testi sonuçları Tablo 4'de gösterilmektedir. Buna göre, veriler normal dağılıma uymadığı için çalışmada yapılacak karşılaştırma testlerinde parametrik olmayan test teknikleri kullanılmıştır.

Tablo 4. Yönetici ve Bankadaki Diğer Çalışanlar Arasındaki İletişim Sorunları Ölçeğinin Normallik Testi

\begin{tabular}{|l|l|l|l|l|c|c|}
\hline \multirow{2}{*}{} & \multicolumn{3}{|l|}{ Kolmogorov-Smirnov } & \multicolumn{3}{|c|}{ Shapiro-Wilk } \\
\cline { 2 - 8 } & İstatistik & sd & $\mathrm{p}$ & İstatistik & $\mathrm{sd}$ & $\mathrm{p}$ \\
\hline $\begin{array}{l}\text { Yönetici ve Bankanı̈ Çalışanları Arasındaki } \\
\text { İletişim Sorunları Ölçek Puanı }\end{array}$ & 0,079 & 227 & $0,001^{*}$ & 0,969 & 227 & $0,000^{*}$ \\
\hline
\end{tabular}

\subsubsection{Yönetici ve Bankadaki Diğer Çalışanlar Arasındaki İletişim Sorunları Ölçek Puanının Cinsiyete Göre Karşılaştırma Testi}

Cinsiyet gruplarının yönetici ve bankadaki diğer çalışanlar arasındaki iletişim sorunlarını algılamaya yönelik ölçek puanı açısından Mann-Whitney U Testi ile yapılan karşılaştırma analizi sonucu Tablo 5'de yer almaktadır.

Tablo 5. Yönetici ve Bankadaki Diğer Çalışanlar Arasındaki İletişim Sorunları Ölçek Puanının Cinsiyete Göre

\begin{tabular}{|l|l|c|c|c|c|}
\hline & Cinsiyet & $\mathrm{n}$ & $\begin{array}{c}\text { Sıra } \\
\text { Ortalaması }\end{array}$ & $\mathrm{U}$ & $\mathrm{p}$ \\
\hline $\begin{array}{l}\text { Yönetici ve Bankadaki Diğer Çalışanlar } \\
\text { Arasındaki İletişim Sorunları Ölçek Puanı }\end{array}$ & Erkek & 115 & 125,76 & \multirow{2}{*}{$5.736,000$} & \multirow{2}{*}{$0,116^{*}$} \\
\cline { 2 - 5 } & Kadın & 112 & 110,36 & \\
\hline${ }^{*} \mathrm{p}<0.05$ & &
\end{tabular}

Analiz sonucunda erkek banka çalışanları ile kadın banka çalışanları arasında yönetici ve bankadaki diğer çalışanlar arasındaki iletişim sorunlarını algılamaya yönelik ölçek puanı açısından istatistiksel olarak anlamlı fark bulunmadığı sonucuna ulaşılmıştır. Yine de erkeklerin yönetici ve diğer banka çalışanları arasındaki iletişim sorunlarına yönelik algısı kadınlara göre daha fazladır. Ancak anlamlı olacak kadar farklı değildir. Bu durum bazı iletişim konularını erkeklerin sorun olarak algıladığı, ancak bu durumların kadınlar tarafından sorun olarak algılanmadığı ya da küçük sorunlar olarak görülüp göz ardı edildiğini göstermektedir.

3.9.2. Yönetici ve Bankadaki Diğer Çalışanlar Arasındaki İletişim Sorunları Ölçek Puanının Yaş Gruplarına Göre Karşılaştırma Testi

Yaş gruplarının yönetici ve diğer banka çalışanları arasındaki iletişim sorunlarını algılamaya yönelik ölçek puanı açısından Kruskal-Wallis H Testi ile yapılan karşılaştırma analizi sonucu Tablo 6 'da yer almaktadır. 
Bankacıllk Sektöründe Örgütsel İletişsim Kaynakl Sorunları...

Tablo 6. Yönetici ve Bankadaki Diğer Çalışanlar Arasındaki İletişim Sorunları Ölçek Puanının Yaş Gruplarına Göre Karşılaştırılması

\begin{tabular}{|c|c|c|c|c|c|}
\hline & Yaş & $\mathrm{n}$ & $\begin{array}{c}\text { Sira } \\
\text { Ortalamas1 } \\
\end{array}$ & $X 2$ & $\mathrm{p}$ \\
\hline \multirow{7}{*}{$\begin{array}{l}\text { Yönetici ve Bankadaki Diğer } \\
\text { Çalışanlar Arasındaki İletişim } \\
\text { Sorunları Ölçek Puanı }\end{array}$} & 25 ve alt 1 & 30 & 91,4 & \multirow{7}{*}{12,856} & \multirow{7}{*}{$0,045^{*}$} \\
\hline & $25-30$ & 35 & 104,68 & & \\
\hline & $30-35$ & 54 & 112,74 & & \\
\hline & $35-40$ & 35 & 111,22 & & \\
\hline & $40-45$ & 30 & 132,56 & & \\
\hline & $45-50$ & 24 & 138,54 & & \\
\hline & 50 ve üzeri & 19 & 151,70 & & \\
\hline
\end{tabular}

Analiz sonucunda farklı yaş grubundan olan banka çalışanları arasında yönetici ve bankadaki diğer çalışanlar arasındaki iletişim sorunlarını algılamaya yönelik ölçek puanı açısından istatistiksel olarak anlamlı fark bulunduğu sonucuna ulaşılmıştır. Yönetici ve diğer banka çalışanları arasındaki iletişim sorunlarını algılamaya yönelik ölçek puanı en düşük olan grup 25 yaş ve altındakiler en yüksek olan grup ise 50 yaş üstündekilerdir.

Yaş arttıkça, ölçek puanı da artmaktadır. Yani yaş arttıkça yönetici ve diğer banka personeli arasındaki iletişim sorunlarına yönelik algı azalmaktadır. Bunun nedeni bazı durumların yaş arttıkça artık sorun olarak algılanmamasıdır. Ayrıca çalışanların artan yaş ile birlikte meslek üzerinde hoşgörü düzeylerinin artması ve tecrübe kazanmaları olabilir. Bunun için çalışanlara verilen hizmet ile ilgili, özellikle birimlerde hizmet içi eğitimler arttırılabilir ve ayrıca çalıştıkları birime adaptasyonları oryantasyon eğitimleri ile sağlanabilir.

\subsubsection{Yönetici ve Bankadaki Diğer Çalışanlar Arasındaki İletişim Sorunları Ölçek Puanının Meslek Gruplarına Göre Karşılaştırma Testi}

Meslek gruplarının yönetici ve diğer banka çalışanları arasındaki iletişim sorunlarını algılamaya yönelik ölçek puanı açısından Kruskal-Wallis H Testi ile yapılan karşılaştırma analizi sonucu Tablo 7'de yer almaktadır.

Tablo 7. Yönetici ve Bankadaki Diğer Çalışanlar Arasındaki İletişim Sorunları Ölçek Puanının Meslek Gruplarına Göre Karşılaştırılması

\begin{tabular}{|c|c|c|c|c|c|}
\hline & Meslek & $\mathrm{n}$ & $\begin{array}{c}\text { Sira } \\
\text { Ortalamas1 }\end{array}$ & $X 2$ & $\mathrm{p}$ \\
\hline \multirow{5}{*}{$\begin{array}{l}\text { Yönetici ve Bankadaki Diğer } \\
\text { Çalışanlar Arasındaki İletişim } \\
\text { Sorunları Ölçek Puanı }\end{array}$} & Servis Memuru & 36 & 152,74 & \multirow{5}{*}{20,910} & \multirow{5}{*}{$0,000^{*}$} \\
\hline & Gişe Görevlisi & 145 & 118,36 & & \\
\hline & Şube Müdürü & 8 & 48,90 & & \\
\hline & Müdür Yardımcısı & 10 & 110,90 & & \\
\hline & $\begin{array}{l}\text { Müşteri İlişkileri ve Satış } \\
\text { Danışmanı }\end{array}$ & 28 & 105,48 & & \\
\hline
\end{tabular}

Analiz sonucunda farklı meslek grubundan olan banka çalışanları arasında yönetici ve bankadaki diğer çalışanlar arasındaki iletişim sorunlarını algılamaya yönelik ölçek puanı açısından istatistiksel olarak anlamlı fark bulunduğu sonucuna ulaşılmıştır.

Servis memurlarının iletişim sorunlarına algıları daha yüksek olup, şube müdürlerinden daha düşüktür. Bunun nedeni her meslek grubunun yöneticilerinin farklı olmasıdır. Bu durum da yöneticilerle en iyi iletişim kuran şube müdürleridir. Şube müdürlerinin en üst bölümü hiyerarşik yapı nedeniyle en üste yakın olmasıdır. Ayrıca şube müdürleri ve gişe görevlilerinin sorunlarının müşserilere yakınlığı ve ilk ilişki kuran çalışanlar olması açısından kritik sorunlar olarak algılanıp, daha kısa sürede çözülmesi gerektiği düşünülerek, şube müdürleri ve gişe görevlilerinin sorunlarına 


\section{F.Ü. Sosyal Bilimler Dergisi 2017-27/1}

öncelik verilmesinden kaynaklanabilir. Bunun için belirli aralıklarla çalışanların tümüne toplam kalite yönetimine yönelik anketler uygulanarak, sorunların tespitine olanak sağlanabilir. Tespit edilen sorunların çözümünde baskıcı bir yol izlemek yerine çalışanlardan oluşan bir çözüm timi meydana getirilebilir.

\subsubsection{Yönetici ve Bankadaki Diğer Çalışanlar Arasındaki İletişim Sorunları Ölçek Puanının Statü Gruplarına Göre Karşılaştırma Testi}

Yöneticiler ile banka çalışanlarının, yönetici ve bankadaki diğer çalışanlar arasındaki iletişim sorunlarını algılamaya yönelik ölçek puanı açısından Mann-Whitney U Testi ile yapılan karşıllaştırma analizi sonucu Tablo 8'de yer almaktadır.

Tablo 8. Yönetici ve Bankadaki Diğer Çalışanlar Arasındaki İletişim Sorunları Ölçek Puanının Statü Gruplarına Göre

\begin{tabular}{|l|l|c|c|c|c|}
\hline & Bankadaki Statü & $\mathrm{n}$ & $\begin{array}{c}\text { Sıra } \\
\text { Ortalaması }\end{array}$ & $\mathrm{U}$ & $\mathrm{p}$ \\
\hline $\begin{array}{l}\text { Yönetici ve Bankadaki Diğer } \\
\text { Çalı̧anlar Arasındaki İletişim } \\
\text { Sorunları Ölçek Puanı }\end{array}$ & Yönetici & 36 & 176,02 & & \\
\cline { 2 - 5 } & Diğer & 191 & 108,35 & \multirow{2}{*}{$1.448,000$} & $0,000 *$ \\
\hline
\end{tabular}

Analiz sonucunda yöneticiler ile banka çalışanları arasında yönetici ve diğer banka çalışanları arasındaki iletişim sorunlarını algılamaya yönelik ölçek puanı açısından istatistiksel olarak anlamlı fark bulunduğu sonucuna ulaşı1lmıştır.

Buna göre yöneticilerin, yönetici ve bankadaki diğer çalışanlar arasındaki iletişim sorunlarını algılamaya yönelik ölçek puanı diğer banka çalışanlarına göre daha yüksektir. Yani yönetici ve diğer banka çalışanları arasındaki iletişimi diğer banka personelleri sorun olarak algılarken, yöneticilerin sorun olarak algılamamasıdır. Bunun nedeni diğer banka çalışanlarının rahat iletişim kuramamasıdır. Ayrıca yöneticilerin bütçe, kalite, hizmet gibi çok daha büyük sorunlarla ilgilenmelerinden dolayı, iletişim sorunlarını daha küçük sorunlar olarak algılanması da olabilir. Yöneticilerin çalışanlar ile ilgili kararlarda çalışanların katılımını yeterince sağlayamamaları çalışanlar açısından sorun olarak düşünülebilir. Bunun çözümü için banka kurumlarındaki yöneticiler ve diğer banka personelinin kurumsal kimliklerini ve her türlü statülerini bir kenara bırakarak, bir psikolog ya da psikolojik danışman gibi bir ruh sağlı̆ğ uzmanı eşliğinde, hep birlikte katılacakları iletişim gruplarının oluşturulması sağlanabilir. Ayrıca, şeffaflık, kurumun her kademesinde olmalıdır. Bunun için alınan kararlar, yapılmak istenen değişiklikler açıkça çalışanlara bildirilmelidir. Böylece çalışanlar önemli oldukları hisseder, işlerine daha çok sahip çıkarlar. Yöneticinin bir duvarın arkasında kalmayı tercih ettiği, çalışanlarla iletişim kurmadığı, bask1 ile işlerin yürüdüğü kurumlarda ister sağl1k ister eğitim ister üretim ile ilgili olsun verimlilikten bahsedilemez. Günümüz dünyası artık klasik yönetici modelinin işlemediği bir dünyadır. Yönetici de ekibin bir parçası olmalıdır ki, yaşanan aksaklıkları görüp önlem alabilsin.

\subsubsection{Yönetici ve Bankadaki Diğer Çalışanlar Arasındaki İletişim Sorunları Ölçek Puanının Meslekte Çalışma Süresi Gruplarına Göre Karşılaştırma Testi}

Meslekte çalışma süresi gruplarının yönetici ve diğer sağlık çalışanları arasındaki iletişim sorunlarını algılamaya yönelik ölçek puanı açısından Kruskal-Wallis H Testi ile yapılan karşılaştırma analizi sonucu Tablo 9'da yer almaktadır. 
Bankacıllk Sektöründe Örgütsel İletişim Kaynakl Sorunların...

Tablo 9. Yönetici ve Bankadaki Diğer Çalışanlar Arasındaki İletişim Sorunları Ölçek Puanının Meslekte Çalışma Süresi Gruplarına Göre Karşılaştırılması

\begin{tabular}{|c|c|c|c|c|c|}
\hline & $\begin{array}{l}\text { Meslekteki Çalışma } \\
\text { Y1lı }\end{array}$ & $\mathrm{n}$ & Sira Ortalamas1 & $\mathrm{X} 2$ & $\mathrm{p}$ \\
\hline \multirow{5}{*}{$\begin{array}{l}\text { Yönetici ve Bankadaki Diğer } \\
\text { Çalışanlar Arasındaki İletişim } \\
\text { Sorunları Ölçek Puanı }\end{array}$} & $0-5$ & 51 & 101,16 & \multirow{5}{*}{3,896} & \multirow{5}{*}{$0,408 *$} \\
\hline & $5-10$ & 76 & 120,22 & & \\
\hline & $10-15$ & 52 & 121,16 & & \\
\hline & $15-20$ & 30 & 118,16 & & \\
\hline & 20 ve üzeri & 18 & 131,13 & & \\
\hline
\end{tabular}

Analiz sonucunda meslekte çalışma süresi farklı olan banka çalışanları arasında yönetici ve bankadaki diğer çalışanlar arasındaki iletişim sorunlarını algılamaya yönelik ölçek puanı açısından istatistiksel olarak anlamlı fark bulunmadığı sonucuna ulaşılmıştır. Fakat yine de yıl arttıkça iletişim sorunu algısının azaldığı görülmektedir. Bunun nedeni çalışma yılı arttıkça uzun süre bankacılık alanında çalışan personelin iletişim sorununa algılarının değiştiği görülmektedir. Yaşla da ilişkilendirildiğinde meslekte uzun süredir çalışanların, aynı zamanda yaş olarak da büyük oldukları düşünüldüğünde iki sonuç birbiriyle tutarlıdır. Sonuç olarak yaş ve meslekte geçen süre arttığında, tecrübe de arttığından eskiden sorun olarak algılanan durumlarının ve iletişim olaylarının zamanla özümsenerek sorun olarak görülmekten çıktığı veya benimsenerek arka plana itildikleri düşünülebilir. Ayrıca emeklilik dönemi yaklaştıkça bireylerin bu sorunlarla ilgilenme yolundaki isteklerin azalması da bu durumu açıklamaktadır. Bu durumun çözümü için özellikle mesleğe yeni başlayan ya da kuruma yeni gelen çalışanlara oryantasyon yapılması da iletişim sorunlarının azalmasına yardımcı olacaktır. Güzel başlangıçlar, sorun algısının azalmasına da yardımcı olacaktır.

\subsubsection{Yönetici ve Bankadaki Diğer Çalışanlar Arasındaki İletişim Sorunları Ölçek Puanının Eğitim Durumu Gruplarına Göre Karşılaştırma Testi}

Eğitim durumu gruplarının yönetici ve diğer banka çalışanları arasındaki iletişim sorunlarını algılamaya yönelik ölçek puanı açısından Kruskal-Wallis H Testi ile yapılan karşılaştırma analizi sonucu Tablo 10'da yer almaktadır.

Tablo 10. Yönetici ve Bankadaki Diğer Çalışanlar Arasındaki İletişim Sorunları Ölçek Puanının Eğitim Durumu Gruplarına Göre Karşılaştırılması

\begin{tabular}{|c|c|c|c|c|c|}
\hline & Eğitim Durumu & $\mathrm{n}$ & $\begin{array}{c}\text { Sira } \\
\text { Ortalamas1 }\end{array}$ & $\mathrm{X} 2$ & $\mathrm{p}$ \\
\hline \multirow{5}{*}{$\begin{array}{l}\text { Yönetici ve Bankadaki Diğer } \\
\text { Çalışanlar Arasındaki İletişim } \\
\text { Sorunları Ölçek Puanı }\end{array}$} & Lise & 29 & 102,41 & \multirow{5}{*}{8,326} & \multirow{5}{*}{$0,075^{*}$} \\
\hline & Ön Lisans & 80 & 116,36 & & \\
\hline & Lisans & 98 & 120,80 & & \\
\hline & Yüksek Lisans & 18 & 138,56 & & \\
\hline & Doktora & 2 & 149,12 & & \\
\hline
\end{tabular}

Analiz sonucunda eğitim durumu farklı olan banka çalışanları arasında yönetici ve bankadaki diğer çalışanlar arasındaki iletişim sorunlarını algılamaya yönelik ölçek puanı açısından istatistiksel olarak anlamlı fark bulunmadı̆̆ sonucuna ulaşılmıştır.

Her ne kadar p değeri anlamlı çıkmasa da, gruplarda ki ölçek puanları incelendiğinde eğitim seviyesi arttıkça ölçek puanının azaldığı, yani eğitim seviyesi arttıkça yönetici ve diğer banka personeli arasındaki iletişim sorunlarına algının azaldığı görülmektedir. İletişim ile ilgili eğitim alma durumunda görüldüğü gibi eğitim alanların sorunlara algıları daha azdır. Bu konuda akademik eğitimin daha fazla fark yarattığı ve daha etkili olduğu görülmektedir. Ayrıca eğitim düzeyi arttıkça yönetici olma ihtimali de artmaktadır. Bu durum statü ile ilişkilendirildiğinde yöneticilerin de yine 
aynı şekilde eğitim düzeyi yüksek olanlarda olduğu gibi sorun olarak algılamadıkları görülmektedir.

\subsubsection{Yönetici ve Bankadaki Diğer Çalışanlar Arasındaki İletişim Sorunları Ölçek Puanının İletişim İle İlgili Daha Önce Eğitim Alma Durumu Gruplarına Göre Karşılaştırılması}

İletişim ile ilgili daha önce eğitim alma durumu gruplarının yönetici ve diğer banka çalışanları arasındaki iletişim sorunlarını algılamaya yönelik ölçek puanı açısından Mann-Whitney U Testi ile yapılan karşılaş̧ırma analizi sonucu Tablo 11'de yer almaktadır.

Tablo 11. Yönetici ve Bankadaki Diğer Çalışanlar Arasındaki İletişim Sorunları Ölçek Puanının İletişim İle İlgili Daha Önce Eğitim Alma Durumu Gruplarına Göre Karşılaştırılması

\begin{tabular}{|l|l|c|c|c|c|}
\hline & $\begin{array}{l}\text { İletişim ile ilgili daha } \\
\text { önce eğitim alıp } \\
\text { almama durumu }\end{array}$ & $\mathrm{n}$ & $\begin{array}{c}\text { Sıra } \\
\text { Ortalaması }\end{array}$ & $\mathrm{U}$ & $\mathrm{p}$ \\
\hline $\begin{array}{l}\text { Yönetici ve Bankadaki Diğer } \\
\begin{array}{l}\text { Çalışanlar Arasındaki İletişim } \\
\text { Sorunları Ölçek Puanı }\end{array}\end{array}$ & Evet & 118 & 121,24 & $6.364,000$ & $0,796^{*}$ \\
\cline { 2 - 4 } & Hayır & 109 & 117,16 & \\
\hline
\end{tabular}

$* \mathrm{p}<0.05$

Analiz sonucunda iletişim ile ilgili daha önce eğitim alma durumu farklı olan banka çalışanları arasında yönetici ve bankadaki diğer çalışanlar arasındaki iletişim sorunlarını algılamaya yönelik ölçek puanı açısından istatistiksel olarak anlamlı fark bulunmadığ 1 sonucuna ulaşılmıştır. Yine de iletişim eğitimi alan personelin daha az sorun olarak algıladığı görülmektedir. Kurum çalışanlarının (yönetici ve diğer personel ile birlikte) ekip ruhu, işbirliği, hoşgörü, yardımlaşma gibi konularda eğitimler almaları sağlanabilir. Ancak bu noktada dikkat edilmesi gereken, eğitimlerin sürekliliğinin sağlanmasıdır. Süreklilik, farkındalığın oluşmasına yardımcı olacak en önemli unsurdur. İletişim eğitimi alan personel ile iletişim eğitimi almayan personel arasında herhangi bir değişiklik görülmemiştir. İletişim eğitiminin algıda değişiklik yapmadığı görülmektedir.

\section{SONUÇ}

Son yıllarda hızla değişen rekabet koşullarına uyum sağlamak, tüm örgütler için önemli bir konu olmuştur. Rekabet koşullarına uyum sağlamak, örgüt amaçları ile bireysel amaçları birleştirmekle, bu da etkin iletişim koşullarıyla mümkün olacaktır. Kurumlarda, özellikle de banka kurumları gibi insanlara hizmet etme amacıyla oluşturulmuş kurumlarda, çalışanların sağlıklı iletişim kuruyor olmaları önem verilmesi gereken noktalardır.

Bankacılık sektöründe faaliyette bulunan kurumlar iş tanımının doğru yapılması, yardımlaşma, işbirliği ve hoşgörünün olması, olumlu eleştirilerin yapılması, sosyo-kültürel farkların göz ardı edilerek birlik ruhunun oluşturulması, kararlar alınırken işi yapanların da fikrinin sorulması ve yüz yüze iletişime önem verilmesi gibi detayların desteklenmesinin kurum kültürüne olumlu katkılar sağlayacağı aşikardır.

Bütün bu nedenlerle, bu çalışmada banka kurumlarındaki yönetici ve diğer personelin iletişim sorunları algısı ve bu algıyı etkileyen demografik özellikler incelenmiştir. Araştırmada banka kurumlarında görev yapan yönetici ve diğer personelin iletişim sorunlarını tespit etmek amaciyla seçilen 5'li likert tipi 'yönetici ve diğer banka çalışanları arasındaki iletişim sorunları ölçeği' bankada çalışan 227 kişiye uygulanmıştır.

Araştırmanın örneklemi incelendiğinde; örneklem grubunun çoğunluğu erkeklerin; yine çoğunluğu 30-35 yaş grubunun, en az da 50 ve üzeri yaş grubunun oluşturduğu görülmektedir. Katılımın çoğunluğunu gişe görevlilerinin, en az da şube müdürlerinin oluşturduğu görülmektedir. Katılımın statü ağırlığı diğer çalışanların oluşturduğu, yöneticilerin sayılarının daha az olduğu ve bankadaki çalışma süresinin en çok olduğu grubu 5-10 yıl çalışan grup oluşturmaktadır. Katılımın olduğu grupta lisans mezunu sayısı fazla olurken doktora mezunu sayısı en azdır. Ayrıca iletişim 
ile ilgili eğitim almış grubun fazla olduğu görülmektedir. Örneklem grubunun demografik özelliklerine ilişkin bu sonuçlar değerlendirildiğinde, araştırmadan elde edilen bulguların genellenebilir nitelikte olduğu söylenebilir.

Yönetici ve diğer banka çalışanları arasındaki iletişim sorunları ifadelerine verilen cevapların dağılımları incelendiğinde ise; araştırma katılımcılarının en çok katıldıkları ifade yöneticiler, mesajlarını sözlü ya da yazılı olarak çalışanlarına bildirirler maddesidir, en az katıldıkları madde ise; yöneticiler ve çalışanlar karş1lıklı eleştiriye açıktırlar maddesidir.

Araştırmanın yedi hipotezi mevcuttur. Yapılan veri analizleri sonucunda 3'ü kabul edilmiş, 4'ü ise kabul edilmemiştir. Araştırma katılımcılarının yönetici ve diğer banka çalışanları arasındaki iletişim sorunları değerlendirmesi cinsiyet, bankadaki çalışma süresi, eğitim düzeyi ve iletişim ile ilgili eğitim alma durumlarına göre farklılık göstermezken, yaş, statü, meslek durumlarında farklılık göstermektedir. Sonuçlar şu şekildedir:

$>$ "Yönetici ve bankadaki diğer çalışanlar arasındaki iletişim sorunlarına yönelik algı erkeklerde kadınlara göre daha fazladır" hipotezi geçerli bulunmamıştır. Buda yönetici ve çalışanlar arasındaki iletişim sorunlarına yönelik algının cinsiyete göre değişmediğini göstermektedir. Analiz sonuçlarına göre erkeklerde kadınlara göre iletişim sorunlarını yönelik algı daha fazladır. Yine de anlamlı olacak kadar farklı değildir.

> "Yönetici ve bankadaki diğer çalışanlar arasındaki iletişim sorunlarına yönelik alg1 yaş arttıkça artmaktadır" hipotezi geçerli bulunmuştur. Buna göre yaş arttıkça ölçek puanı da artmaktadır. Yani yaş arttıkça yönetici ve diğer banka çalışanları arasındaki iletişim sorunlarına yönelik algı azalmaktadır.

> "Yönetici ve bankadaki diğer çalışanlar arasındaki iletişim sorunlarına yönelik algı müdür yardımcılarında diğer banka çalışanlarına göre fazladır" hipotezi geçerli bulunmuştur.

$>$ "Yönetici ve bankadaki diğer çalışanlar arasındaki iletişim sorunlarına yönelik alg1 yöneticilere göre diğer banka personelinde daha fazladır" hipotezi geçerli bulunmuştur. Yöneticilerin ölçek puanı sıra ortalaması yüksek, diğer banka çalışanlarının ise düşüktür. Buna göre yöneticilerin, yönetici ve diğer banka çalışanları arasındaki iletişim sorunlarını algılamaya yönelik ölçek puanı diğer banka çalışanlarına göre daha yüksektir.

> "Yönetici ve bankadaki diğer çalş̧anlar arasındaki iletişim sorunlarına yönelik alg1 meslekte çalışma yılı arttıkça artmaktadır" hipotezi geçerli bulunmamıştır. Analiz sonuçlarına baktığımızda meslekteki çalışma yılı arttıkça iletişim sorunlarına yönelik algının azaldığı görülmektedir. Mesleğe yeni başlayan personelin aralarındaki iletişimi sorun olarak algılamamaları için yöneticilerin sağlıklı bir iletişim ortamı hazırlamaları ve yeni başlayan personele karşı daha hoşgörülü davranmaları gerekmektedir.

> "Yönetici ve bankadaki diğer çalışanlar arasındaki iletişim sorunlarına yönelik alg1 eğitim düzeyi arttıkça artmaktadır" hipotezi geçerli bulunmamıştır. Fakat yine de eğitim düzeyi arttıkça iletişim sorunlarına yönelik algının daha az olduğu görülmektedir. Bu durum eğitim seviyesi yüksek olan bireylerin iletişim sorunlarına algıları ile eğitim seviyesi düşük olan çalışanın iletişim sorunlarına bakış açılarının biraz farklı olduğunu göstermektedir.

> "Yönetici ve bankadaki diğer çalışanlar arasındaki iletişim sorunlarına yönelik algı iletişim ile ilgili daha önce eğitim alanlarda almayanlara göre daha fazladır" hipotezi geçerli bulunmamıştır. Analize göre iletişim ile ilgili daha önce eğitim alan çalışanın daha az sorun olarak algıladığ1 görülmüştür. Bunun sebebinin iletişim ile ilgili eğitim almış çalışanın nasıl iletişim kurması gerektiğini bilmesi ve sorunları nasıl çözebileceği konusunda eğitim almış olması olabilir.

\section{KAYNAKÇA}

ALPERGiN, P., (1990). Bireysel Bankacılık, Türkiye Bankalar Birliği Araştırma ve Yayın Grubu, Yayın No:160, İstanbul.

ARSLAN, Ramazan, (2008). Türk Bankacılık Sisteminde Rekabet Stratejileri ve Yayllım Süreci, Uşak Üniversitesi Sosyal Bilimler Dergisi, 1/2, s.125-141. 


\section{F.Ü. Sosyal Bilimler Dergisi 2017-27/1}

ATLI, Y., ve DEMİR. Ö., (2015). Bankacılık Sektörü ve Elazığ’da Bankacıllı̆̆ın Gelişimi, Fırat Üniversitesi Harput Araştırmalar Dergisi, Cilt II, Sayı 1, s.111-123.

AYIK, Ahmet ve FIDAN, Mustafa, (2014). İlköğretim Kurumlarında Örgütsel İletişim İle Okul Kültürü Arasındaki İlişki, Mehmet Akif Ersoy Üniversitesi Eğitim Fakültesi Dergisi, Sayı 29, s.108-134.

BDDK, (2015). Türk Bankacılık Sektörü Temel Göstergeleri, Eylül.

DEMIREL, Y., SEÇKIN, Z., ve ÖZÇINAR, M.F., (2011). Örgütsel İletişim İle Örgütsel Vatandaşlık Davranışı Arasındaki İliş̧ki Üzerine Bir Araştırma, Ç.Ü. Sosyal Bilimler Enstitüsü Dergisi, Cilt 20, Sayı 2, s.33-48.

DEMIRTAŞ, Mine, (2010). Örgütsel İletişimin Verimlilik ve Etkinliğinde Yararlanılan İletişim Araçları ve Halkla İlişkiler Filmleri Örneği, Marmara Üniversitesi İ.İ.B.F. Dergisi, Cilt 28, Sayı 1, s. 411-444.

DURĞUN, Serpil, (2006). Örgüt Kültürü ve Örgütsel İletişim, Yüzüncü Yıl Üniversitesi Eğitim Fakültesi Dergisi, Cilt 3, Sayı 2, s.112-132.

KAYA, S., (1992). "Hastanelerde Örgütsel Çatışmanın Nedenleri”, Hacettepe Sağlık İdaresi Dergisi, Cilt I, Sayı 1, s.71-99.

KÜÇÜK, M. (1993). Bireysel Bankacılık, Otomasyon ve Türkiye'de Bireysel Bankacılık, Uzman Gözüyle Bankacılık Dergisi.

OĞUZ, D., (2010). Hizmet Kalitesi ve Bankacılık Sektöründe Hizmet Kalitesinin Servqual Yöntemiyle Ölçümüne Yönelik Bir Uygulama, Yüksek Lisans Tezi.

SAĞBAŞ, N.Ö., (2013). İletişim, Örgütsel İletişim ve Okul Yönetimi, Beykent Üniversitesi Sos.Bil.Ens. Yayımlanmış Yüksek Lisans Tezi, İstanbul.

ŞAKAR, Hakan, (2000). Genel Bankacılık Bilgileri, Strata Yayıncıllk, Yayın No:4, İstanbul.

ULUKUŞ, K.S., (2010). Örgütsel İletişim Örüntüsünün Kurum İçi İlişkilerdeki Önemi (Aksaray İl Emniyet Teşkilatında Uygulamalı Bir Çalışma), Selçuk Üniversitesi Sos.Bil.Ens. Yayımlanmış Doktora Tezi, Konya.

UZKESİĊ, Nuray, (1994). Modern Banka Yönetimi ve Organizasyonu, Anadolu Üniversitesi Yayınları, No:784, Eskişehir.

YATKIN, A. ve YATKIN, Ü.N., (2015). Halkla İlişkiler ve İletişim, Nobel Akademik Yayıncılık, 4.Basım, Ankara.

YETIM, S., (1997). Kredi Kartları ve Tüketici Kredileri, İstanbul: Sermaye Piyasası Kurulu Yayınları No: 69, 1997:4.

YÜKSEL H.A., (2007). Araştırma Görevlilerinin İş Tatmini Sağlama Aracı Olarak Örgütsel İletişim ve İletişim Doyumu: Kamu ve Özel Üniversite Karşılaşıırması, Selçuk Üniversitesi Sos.Bil.Ens. Yayımlanmış Doktora Tezi, Konya.

http://www.gundemim.net/bankalarda-alimi-yapilan-pozisyonlar-ve-gorevleri, erişim tar., (08/03/2016). 